\title{
Economic evaluation and efficacy of strategic-selective treatment of gastrointestinal parasites in dairy calves
}

Avaliação econômica e eficácia do tratamento estratégico-seletivo de parasitos gastrointestinais em bezerras leiteiras

Yuly Andrea Caicedo Blanco ${ }^{1}$; Jonata de Melo Barbieri'i ${ }^{1}$ Renato Ribeiro de Lima²; Marcos Aurélio Lopes ${ }^{3}$; Eduardo Mitke Brandão Reis ${ }^{1}$; Christiane Maria Barcellos Magalhães da Rocha ${ }^{3}$; Adriana de Souza Coutinhoº Antônio Marcos Guimarães ${ }^{3 *}$

\author{
${ }^{1}$ Programa de Pós-graduação em Ciências Veterinárias - PPGCV, Universidade Federal de Lavras - UFLA, Lavras, MG, Brasil \\ ${ }^{2}$ Departamento de Ciências Exatas, Universidade Federal de Lavras - UFLA, Lavras, MG, Brasil \\ ${ }^{3}$ Departamento de Medicina Veterinária, Universidade Federal de Lavras - UFLA, Lavras, MG, Brasil
}

Received October 27, 2016

Accepted March 7, 2017

\begin{abstract}
In the Experimental Farm of the Universidade Federal de Lavras (EF-UFLA), state of Minas Gerais, Brazil, on their day of birth, female Holstein calves were randomly selected and placed into two groups containing fifteen animals each: Strategic-Selective Treatment (S-ST) or Conventional Treatment (CT). In the S-ST, calves were treated after coproparasitological examinations according to criteria established previously by the researchers. Calves in the CT were treated according to the opinion of the veterinarian of EF-UFLA. For statistical analysis, the frequency (\%) of fecal samples with count of eggs per gram of feces (EPG) $\geq 300$, count of oocysts per gram of feces (OoPG) $\geq 500$ and fecal samples with count of cysts of Giardia spp. $\geq 1$ were conducted. The overall average frequency of fecal samples with EPG $\geq 300$, OoPG $\geq 500$ and Giardia spp. cysts $\geq 1$, respectively, was similar ( $>0.05)$ between S-ST $(20.3 \%$; 17.3\%; and $31.5 \%)$ and CT $(26.4 \% ; 23.9 \%$; and 37.3\%). The effective operational cost, per animal, in 12 months, was of $\mathrm{R} \$ 784.58$ (US\$2 241.41) and R 83.90 (US\$ 25.81) in S-ST and CT, respectively. The S-ST requires adjustments to be used as a technically efficient and economically viable alternative for the control of gastrointestinal parasitosis in female Holstein calves.
\end{abstract}

Keywords: Bovine, gastrointestinal nematodes, Eimeria, Giardia, costs.

\section{Resumo}

$\mathrm{Na}$ Fazenda Experimental da Universidade Federal de Lavras (FE-UFLA), Minas Gerais, Brasil, no dia do nascimento, bezerras da raça holandesa foram sorteadas de forma aleatória para compor um dos dois grupos, formados por 15 animais cada: Tratamento Estratégico-Seletivo (TE-S) ou Tratamento Convencional (TC). No TE-S, as bezerras foram tratadas após exames coproparasitológicos de acordo com critérios previamente estabelecidos pelos pesquisadores. No TC, as bezerras foram tratadas conforme orientação do veterinário da FE-UFLA. Em ambos grupos, as bezerras foram monitoradas a cada 14 dias, do nascimento até os 12 meses de idade, por meio de exames coproparasitológicos. Para análise estatística, considerou-se a frequência (\%) de amostras fecais com contagem de ovos por grama de fezes (OPG) $\geq 300$, contagem de oocistos por grama de fezes $(\mathrm{OoPG}) \geq 500$, e amostras fecais com contagem de cistos de Giardia spp. $\geq 1$. A frequência média global de amostras fecais com contagem de $\mathrm{OPG} \geq 300$, OoPG $\geq 500$ e cistos de Giardia spp. $\geq 1$, respectivamente, foi similar ( $>>0,05)$ entre TE-S $(20,3 \% ; 17,3 \%$; e $31,5 \%)$ e TC $(26,4 \% ; 23,9 \%$; e $37,3 \%)$. O custo operacional efetivo, por animal, em 12 meses, foi R \$ 784,58 (US\$241.40) e R \$ 83,90 (US\$25.81) para TE-S e TC, respectivamente. O TE-S necessita de ajustes para que possa ser indicado como uma alternativa, tecnicamente eficiente e economicamente viável, no controle das parasitoses gastrointestinais em bezerras leiteiras.

Palavras-chave: Bovino, nematódeos gastrointestinais, Eimeria, Giardia, custos. 


\section{Introduction}

Brazil possesses one of the largest cattle herd in the world, with about 210 million of head (BRASIL, 2014). Nevertheless, the health of the herds has been one of the main challenges to be faced, chiefly with relation to the diseases of parasitic etiology responsible for expressive economic losses in Brazil; standing out gastrointestinal nematodes (GINs) which cause a yearly loss of seven billion of dollars (GRISI et al., 2014).

In intensive dairy production systems, damage caused by GINs in cattle is amplified, leading for intensive use of anthelmintic drugs. Generally, these products are administered based on a single criterion, namely the physical condition of the animal. It is therefore characterized as a conventional treatment, since it is adopted by the majority of dairy farms (ANTONELLO et al., 2010; KENYON \& JACKSON, 2012). However, to delay the emergence of resistance and reduce costs with treatments, the selective treatment appears as an alternative. In the selective treatment only animals with high infection levels, identified by stool tests, are treated rather than treating the entire herd (O'SHAUGHNESSY et al., 2015).

In the control of eimeriosis, disease characterized by aqueous diarrhea (DAUGSHIES \& NAJDROWSKI, 2005), previous studies have shown the efficiency of prophylactic treatment with toltrazuril (MUNDT et al., 2005). The prophylactic use of fenbendazole has been shown to be efficient in the control of giardiasis in young dairy cattle, which is seen in high frequency and results in chronic diarrhea and weight loss in cattle (O'HANDLEY \& OLSON, 2006; GEURDEN et al., 2010), and may have negative a impact on growth performance in calves (GEURDEN et al., 2006).

The objective of this study was to evaluate economic aspects of the strategic-selective treatment and its efficacy to control of gastrointestinal parasitic diseases in female Holstein calves.

\section{Materials and Methods}

\section{Study site and animals}

The present study was conducted at the Experimental Farm of the Universidade Federal de Lavras (FE-UFLA) located in the municipality of Ijaci $\left(21^{\circ} 10^{\prime} 12^{\prime \prime} S\right.$ and $\left.44^{\circ} 55^{\prime} 30^{\prime \prime} \mathrm{W}\right)$, state of Minas Gerais, Brazil, from April 2013 to November 2014, after approval had been obtained from the Ethical Committee of the Use of Animals in Research of the UFLA and registered under the number $106 / 12$. The climate of the region is characterized by a dry winter (April to September) and rainy summer (October to March), with a total annual average rainfall of $1,530 \mathrm{~mm}$ and an average annual temperature of $19.4^{\circ} \mathrm{C}$ (DANTAS et al., 2007).

The herd consisted of 51 Holstein cows, which were lactating and confined to a free stall, having an average production of $20 \mathrm{~L}$ of milk per cow per day. After birth, the female Holstein calves received $4 \mathrm{~L}$ of their mother's colostrum in a bottle for up to $4 \mathrm{hr}$. During the suckling phase, the calves were housed in individual pens with a concrete floor lined with hay and chopped grass, which was changed twice a week on average. The animals received pelletized concentrate, ad libitum, plus $200 \mathrm{~g}$ of milk replacer per day. They were also provided with $6 \mathrm{~L}$ of milk daily, $3 \mathrm{~L}$ in the morning and $3 \mathrm{~L}$ in the evening, until 2 months of age, and from 3 months of age, $3 \mathrm{~L}$ of milk was daily given in the mornings. At 90 days of age, the calves were weaned abruptly, weighing about $100 \mathrm{~kg}$ of live weight, and moved to rearing paddocks containing Tifton (Cynodon spp.), to compose one of the two experimental groups. In these paddocks, which had previously been used by cattle during the growing phase, calves received corn silage (ad libitum) and $3 \mathrm{~kg}$ of concentrate per animal per day. The paddocks intended for a phase of the growing period (from weaning to 12 months old) presented an area of cemented and shaded trough, in addition to cemented tanks for continuous flow water supply, controlled by buoy and for mineral salt. The female Holstein calves were given compulsory vaccines against aftosa fever and brucellosis at the adequate times.

\section{Experimental animals}

Shortly after birth, female Holstein calves were selected randomly to undergo one of two groups, the strategic-selective treatment (S-ST) or the conventional treatment (CT), with each treatment group consisting of 15 animals. Female Holstein calves which were born from twin deliveries or with some apparent problem, which could endanger their development, were not included in the experiment. Calves were monitored every fourteen days from birth until they reached one year of age.

\section{Strategic-Selective Treatment (S-ST)}

The S-ST was based on two fundamental premises, i.e., the best time to treat the animals and identification of animals that required treatment. The timing for administration of GINs control was based on a previous study of dairy calves in the state of Minas Gerais (GUIMARÁES et al., 2000). Values of the degree of infection (cut point), according to the individual count of Strongylidae-type eggs (EPG), were utilized to confirm S-ST. Only animals with nematode (family Strongylidae) egg counts per gram of feces (EPG) $\geq 300$ (HOFFMANN, 1987) were treated. For the control of Eimeria spp., the timing was based on another previous study of dairy calves (SÁNCHEZ et al., 2008), and only animals with oocyst count per gram of feces (OoPG) $\geq 500$ were treated (BANGOURA et al., 2012). Prophylactic treatment for Giardia spp. was based on a study of dairy calves in the state of Minas Gerais (SILVA et al., 2011).

In the S-ST, the control of gastrointestinal parasitosis was achieved using the following: (1) for treatment of GINs (worms), administration of $3.5 \%$ ivermectin $\left(0.2 \mathrm{mg} \mathrm{kg}^{-1}\right.$, by subcutaneous injection, Ranger ${ }^{\circledR}$, Vallée) individually, whenever EPG were $\geq 300$, at weaning (90 days of age) and during April, July, October, and January, regardless of age, until the end of the first year; (2) for treatment of Eimeria spp., toltrazuril $\left(15 \mathrm{mg} \mathrm{kg}^{-1}\right.$, oral treatment, Baycox ${ }^{\circledR}$, Bayer) was administered at 21 days of age, during weaning and individually, whenever OoPG were $\geq 500$, regardless of age, until the end of the first year; and (3) for treatment of Giardia spp., $10 \%$ fenbendazole $\left(15 \mathrm{mg} \mathrm{kg}^{-1}\right.$, oral treatment, Panacur $\left.{ }^{\circledR}, \mathrm{MSD}\right)$ 
was given at 28 days of age, during weaning and the treatment was repeated after 28 days.

Before it was utilized, 3.5 ivermectin was not tested as to its anthelmintic resistance in FE-UFLA. After the end of the experiment according to the result of the count of EPG in S-ST, the fecal egg-count reduction test (FECRT, in vivo - indirect), to detect the resistance of 3.5 ivermectin to GINs in FE-UFLA was tested. The arithmetic mean of the count of EPG in the stools of the same animals both before and 14 days after the anthelmintic treatment, according to the methodology proposed by Dobson et al. (2012) were utilized. Consider there is anthelmintic resistance when FECRT is lower than 95\% (COLES et al., 1992).

\section{Conventional Treatment (CT)}

For CT dairy calves, there were no criteria defined about the need and best time for the control of the gastrointestinal parasitosis control, neither periodical coproparasitological examinations were carried out. The calves were treated according to the opinion of the veterinarian of FE-UFLA, when apparent clinical signs appeared, or when judged necessary by the caretaker, depending on the animal's condition. The only antiparasitic product administered, which is specifically used for the control of GINs, was 3.5\% ivermectin (0.2 $\mathrm{mg} \mathrm{kg}^{-1}$, subcutaneous treatment, Ivomec ${ }^{\circledR}$ Gold, Merial) and in cases of diarrhea, enrofloxacin $\left(10 \mathrm{mg} \mathrm{kg}^{-1}\right.$, subcutaneous treatment, Quinotril ${ }^{\circledR}$, Vallée).

\section{Coproparasitological analysis and weighing}

Faeces samples (10-15 g) were collected from the rectum of the calves every 14 days. For fecal score (FS), calves with firm or pasty faeces were considered normal, while calves with liquid or semi-liquid faeces were considered as experiencing diarrhea (MUNDT et al., 2005). For individual EPG and OoPG, the modified McMaster technique with a sensitivity of 50 eggs (EPG) and 50 oocysts (OoPG) was used (GORDON \& WHITLOCK, 1939). Pool of faeces from animals with EPG $\geq 300$ were used to perform the larvae cultures (ROBERTS \& O'SULLIVAN, 1950). In each sample combination, 100 larvae were randomly counted and the results expressed as the ratio of recovered infective larvae $\left(\mathrm{L}_{3}\right)$. The identification of Strongylidae $\mathrm{L}_{3}$ was based on criteria established by Ueno \& Gonçalves (1998). Mixed faeces samples with OoPG $\geq 500$ were allowed to sporulate in Petri dishes with $2.5 \%$ potassium dichromate solution for seven days in a BOD incubator. For identification, 100 sporulated oocysts were randomly counted, and the species identified according to parameters proposed by Ernst \& Benz (1986). The zinc sulfate at 33\% flotation technique was used for the detection of Giardia spp. (HUBER et al., 2003). The coproparasitological examinations were conducted in the Laboratory of Parasitic Diseases of UFLA.

The average daily weight gain (ADWG) (arithmetic mean) was estimated every 14 days from measuring the animals using a tape measure. The ADWG was calculated as the difference between the initial and final weight of the animals in the S-ST and CT groups divided by the number of days in the sampling period.

\section{Statistical and economic analysis}

Firstly, all qualitative variables were categorized and transformed into dichotomous. To test the statistical differences between the two groups of calves, the treatment was considered the independent variable, i.e., S-ST or CT.

To compare the parasitological results between groups, the dependent variables were FS (normal or pasty feces=1, semi-liquid or liquid feces=2), EPG ('infection subjected to treatment' $\geq 300$, 'low infection' <300), OoPG ('infection subjected to treatment' $\geq 500$, 'low infection' $<500$ ), and Giardia spp. (positive sample $\geq 1$ cyst, negative sample $=0$ ). Univariate analysis was performed by chi-square $\left(x^{2}\right)$ or Fisher's exact test (less than five observations in at least one cell in the contingency table). Variables associated $(\mathrm{P}<0.05)$ were selected to build the multiple models. We calculated the strength of association (or risk) by adjusted odds ratio (OR) and its confidence interval of $95 \%$ by logistic regression.

ADWG was determined from weight measurements taken every 14 days. Normality was tested using the Kolmogorov-Smirnov and Student's T test, to determine whether there was a difference in ADWG between the groups $(\mathrm{p}<0.05)$.

All the results of the statistical analysis were obtained in the Statistic SAS (SAS Institute, 2004) and SPSS 18.0 (IBM, 2014).

In the economic analysis, all the operating expenses for administering the treatments were computed and divided into the following groups: coproparasitological examinations, expenditure on drugs and material for application of drugs. The component labor was not taken into account in the effective operating cost (EOC), because the employees (calf handler and veterinary) belonged to the perment staff the UFLA.

\section{Results and Discussion}

There was no significant difference $(p>0.05)$ in the overall average frequency of the fecal samples EPG $\geq 300$ in the S-ST $(20.27 \% ; 74 / 365)$ than in the CT $(26.43 \%$; 83/314). This result can be partially explained by the resistance of FE-UFLA nematodes to $3.5 \%$ ivermectin, because the efficacies was low in FECRT $(61.14 \% \pm 26.99 \%)$, which is a phenomenon already confirmed by other researchers in the state of Santa Catarina (SOUZA et al., 2008). In a previous study in state of Minas Gerais that examined mixed Gir-Holstein (F1) calves at six months of age using eight treatments with products based on macrocyclic lactones (Da COSTA et al., 2011), the strategic treatment $(3.15 \%$ ivermectin) administered at the beginning and end of the rainy season showed no significant differences $(p>0.05)$ in the EPG than for the handling adopted in the dairy property. This result corroborates the findings obtained in the present study, indicating the occurrence of anthelmintic resistance, especially to macrocyclic lactones, a phenomenon already confirmed in the state of Mato Grosso do Sul (BORGES et al., 2015). In the S-ST group in the present study, the administration of $10 \%$ fenbendazole (for the control of Giardia spp.), even when associated with 3.5\% ivermectin that is an active ingredient having different mechanisms of action, did not show a statistical difference $(p>0.05)$ in the overall average frequency of fecal samples with EPG $\geq 300$ than 
in the CT. The overall mean of the EPG count (arithmetic mean and standard deviation) per animal at the end of 12 months, was $452.53 \pm 355.57$ for S-ST and $783.93 \pm 529.20$ for CT. In the S-ST, the average number of anthelmintic treatments (arithmetic mean and standard deviation) per animal at the end of 12 months was $8.27 \pm 3.47$, number regarded as high, which corroborates the phenomenon of resistance for GINs in the FE-UFLA, determined by the FECRT $<95 \%$.

In the coproculture (larvae cultures), in both groups (S-ST or CT), seven genera of nematodes were identified: Bunostomum spp., Cooperia spp., Haemonchus spp., Oesophagostomum spp., Ostertagia spp., Strongyloides spp., and Trichostrongylus spp. In the S-ST, depending on the age group, the identified genera of nematodes were Haemonchus spp. (37.0\%; 0-90 days old), Cooperia spp. (33.3\%; 91-180 days old), and Trichostrongylus spp. (58.9\%, 181-365 days old). In the CT, from 0 to 90 days old, it was not possible to estimate the frequency of nematode genera owing to low EPG, and there was a predominance of Trichostrongylus spp. from 91 to 180 days old (35.3\%) and from 181 to 365 days old $(53.8 \%)$. In a previous study on dairy calves in the state of Minas Gerais, during coproculture there were only a few Trichostrongylus spp. in the first four months of life, with Cooperia spp. predominating, and Haemonchus spp. were identified in subsequent months (Da COSTA et al., 2011); corroborating the results of the present study, except for Trichostrongylus spp. Probably, at S-ST, the infection of the female calves by GINs in the pre-weaning phase ( 0 to 90 days of age), occurred by the contamination of the water consumed by the animals or due to the consumption of chopped grass still wet mixed with the hay which was used to line the stalls in the calf houses.

The overall average frequency of the fecal samples with OoPG $\geq 500$, showed no statistical difference $(\mathrm{p}>0.05)$ between S-ST $(17.26 \%$; 63/365) and CT $(23.88 \%$; 75/314). However, in France, prophylactic treatment of calves from 21 to 55 days of age with toltrazuril and monitored for 78 days, reduced the impact of coccidiosis (oocyst excretion, fecal score, and weight gain) in comparison to untreated animals (PHILIPPE et al., 2014). The overall mean of OoPG (arithmetic mean and standard deviation) per animal at the end of 12 months was $958.66 \pm 1,923.95$ and $1,002.71 \pm 1,643.66$ for S-ST and CT, respectively. In S-ST, the average number of treatments with toltrazuril (arithmetic mean and standard deviation) per animal, at the end of 12 months was $4.0 \pm 1.6$, staying above the expected and suggesting that there were failures in the cleaning of the installations of the calf house and in the management of faeces in the growing paddocks of the dairy calves in FE-UFLA, exposing these animals to a high contamination by coccidian parasites of the genus Eimeria spp, a fact corroborated by the high count of OoPG.

In both treatments (S-ST or CT), six species of Eimeria spp. were identified: E. alabamensis, E. auburnensis, E. bovis, E. ellipsoidalis, E. subspherica, and E. zuernii. In the S-ST, from 0 to 90 days old, the most common species were E. bovis (70\%), E. auburnensis (12\%), and E. zuernii (11\%). From 91 to 180 days old, the most common species were E. bovis (49\%), E. ellipsoidalis (16\%), and E. subspherica (14\%). In the CT, from 0 to 90 days old, the most common species were E. bovis (66\%), E. auburnensis (26\%), and E. zuernii (4\%), and from 91 to 180 days old, E. bovis
(43\%), E. subspherica (32\%), and E. zuernii (14\%) were the most common species found. In the 181-365 days old age group, in both treatments, it was not possible to estimate the frequency of Eimeria spp., owing to low OoPG. Eimeria bovis was the most frequent in both groups, a species that, together with $E$. zuernii, has a large distribution in Brazil (ALMEIDA et al., 2011; BRUHN et al., $2011,2012 b$ ). Very young cattle (0 to 90 days old) in general become infected with E. bovis and E. zuernii (DAUGSHIES \& NAJDROWSKI, 2005), confirming the findings of the current study. According to Forslid et al. (2015), the elimination of oocysts of E. zuernii is not age-dependent, however, oocysts of $E$. bovis tend to increase with age of the calves, corroborating the results obtained in the current study in FE-UFLA.

There was no statistical difference $(p>0.05)$ in the overall average frequency of fecal samples with the count of Giardia spp. cysts $\geq 1$ between the S-ST $(31.50 \% ; 115 / 365)$ and the CT (37.26\%; 117/314), probably owing to the high level of Giardia spp. cysts in the environment, and due to rapid re-infection of the animals after treatment with fenbendazole (O'HANDLEY et al., 2000), leading to failure of treatment (O'HANDLEY et al., 2003), because only a low number of Giardia cysts is needed for infection (CACCIÒ et al., 2005). The arithmetic mean and standard deviation of cysts of Giardia spp. in fecal samples per animal at the end of 12 months was $30.06 \pm 43.99$ for S-ST and $73.86 \pm 114.89$ for CT.

There was a statistically significant decrease $(\mathrm{p}<0.05)$ in the overall average diarrheal frequency of fecal samples in the S-ST (9.69\%; 34/351) than in the CT $(19.16 \% ; 55 / 287)$. Diarrhea in calves has a multifactorial etiology, and the identification of agents was beyond the scope of the present study. Most likely, the beneficial action of the S-ST justifies, in part, this result by reducing, when no statistically significant $(p>0.05)$, of level of infection by parasitic agents causing diarrhea in young cattle (CARVALHO et al., 2014).

There was no statistical difference $(\mathrm{p}>0.05)$ in the ADWG (g), per animal, between S-ST $\left(580 \mathrm{~g} \mathrm{day}^{-1}\right)$ and CT $\left(570 \mathrm{~g} \mathrm{day}^{-1}\right)$, which were both lower than expected for well-fed female Holstein calves ( $\left.800 \mathrm{~g} \mathrm{day}^{-1}\right)$ (CAMPOS \& LIZIEIRE, 2005). The overall average weight at one year of age was statistically similar $(\mathrm{p}>0.05)$ between S-ST $(246.7 \pm 27.5 \mathrm{~kg})$ and the CT $(237.3 \pm 26.5 \mathrm{~kg})$. In relation to the age range of the dairy calves ( 0 to 90 ; 91 to 180 ; and 181 to 365 days of age), there was no significant difference ( $p>0.05)$ in ADWG between S-ST $(710 \pm 200 \mathrm{~g} ; 370 \pm 100 \mathrm{~g}$; and $640 \pm 100 \mathrm{~g})$ and CT $(730 \pm 100 \mathrm{~g} ; 300 \pm 200 \mathrm{~g}$; and $640 \pm 100 \mathrm{~g}$ ), respectively. Those results suggest that another factor, distinct from the lack of efficiency of S-ST, may have influenced GPD. The hypothesis is that failure may have occurred in the nutritional management of the dairy calves, particularly in the age range between 91 and 180 days of age, justifying, in part, the poor ADWG observed in both the treatments.

The EOC, per animal, was of R 784.58 (US\$ 241.41) and R\$ 83.90 (US\$ 25.81) in S-ST and CT, respectively (Table 1). The main differences were owing to the significant expenditure on laboratory tests, mainly for feces examination (91.47\% of COE). That attitude, however, is fundamental to identify the animals which, in fact, need treatment and, thus, to apply, in a rational and efficient way, the antiparasitic products (ÁLVAREZ-SANCHEZ et al., 
Table 1. Effective operational cost (EOC) per animal, when completed 12 months of age, of the strategic-selective treatment (S-ST) and conventional treatment (CT) of gastrointestinal parasitic infections in female Holstein calves in experimental farm of UFLA, MG, Brazil.

\begin{tabular}{|c|c|c|c|c|}
\hline \multirow{3}{*}{ Variable } & \multicolumn{2}{|c|}{ S-ST } & \multicolumn{2}{|c|}{ CT } \\
\hline & $\mathbf{R} \$$ & $\%$ of EOC & R\$ & $\%$ of EOC \\
\hline & (US\$) & $\%$ or EUC & (US\$) & $\%$ Or LU \\
\hline \multirow{2}{*}{ Coproparasitological examinations* } & 717.71 & 91.47 & - & - \\
\hline & $(220.83)$ & & - & - \\
\hline \multirow{2}{*}{ Material for the application of drugs } & 37.22 & 4.74 & $(38.93)$ & 46.40 \\
\hline & $(11.45)$ & & $(11.98)$ & \\
\hline \multirow{2}{*}{ Expenditure on drugs } & 29.65 & 3.78 & 44.97 & 53.60 \\
\hline & $(9.12)$ & & $(13.84)$ & \\
\hline \multirow{2}{*}{ Total EOC } & 784.58 & 100.0 & 83.90 & 100.0 \\
\hline & $(241.41)$ & & $(25.81)$ & \\
\hline
\end{tabular}

*Coproparasitological examinations: EPG (egg counts per gram of feces), OoPG (oocyst counts per gram of feces), search for Giardia spp. cysts, and coproculture (larvae cultures).

2005). The amount spent on medicine in the S-ST was $34.07 \%$ lower than in the CT. The rational use of antiparasitic medications contributes to delay the onset of resistance (CHARLIER et al., 2012), and only few studies have analyzed the economic aspects of the control of GINs in dairy cattle in different age groups (BRUHN et al., 2012a, 2013).

The results of S-ST lay below the expected and point out that before the implantation of a program of strategic control of gastrointestinal parasitosis, first of all, it is fundamental to select an anthelmintic with proved efficacy; in the second place, to have enhanced attention to the cleaning practices of the installations intended to the husbandry of the dairy calves aiming to reduce the reinfection level after the antiparasitaric treatment; and last, to give special attention to the nutritional management of dairy calves, avoiding subnutrition and risk for immunosuppression.

In conclusion, the strategic-selective treatment (S-ST) presented no advantages in average daily weight gain and in control of gastrointestinal nematodes, Eimeria spp. and Giardia ssp. in dairy calves, when compared with the conventional treatment (CT), and requires adjustments so that it can be implemented as a technically efficient and economically feasible alternative for the control of gastrointestinal parasitosis in female Holstein calves.

\section{Acknowledgements}

The authors thank the Research Support Foundation of the State of de Minas Gerais (Fundação de Amparo à Pesquisa do Estado de Minas Gerais, FAPEMIG), for financial support (CBB APQ-00855/13).

\section{References}

Almeida VA, Magalhães VCS, Muniz ESM Na, Munhoz AD. Frequency of species of the genus Eimeria in naturally infected cattle in Southern Bahia, Northeast Brazil. Rev Bras Parasitol Vet 2011; 20(1): 78-81. PMid:21439239. http://dx.doi.org/10.1590/S1984-29612011000100017.

Álvarez-Sánchez MA, Pérez-García J, Cruz-Rojo MA, Rojo-Vázquez FA. Real time PCR for the diagnosis of benzimidazole resistance in trichostrongylids of sheep. Vet Parasitol 2005; 129(3-4): 291-298. PMid:15845285. http://dx.doi.org/10.1016/j.vetpar.2005.02.004.

Antonello AM, Cezar AS, Sangioni LA, Vogel FSF. Eggs per gram of feces counting for anthelmintic control in dairy cattle of distinct age groups. Cienc Rural 2010; 40(5): 1227-1230. http://dx.doi.org/10.1590/ S0103-84782010005000067.

Bangoura B, Mundt HC, Schmäschke R, Westphal B, Daugschies A. Prevalence of Eimeria bovis and Eimeria zuernii in German cattle herds and factors influencing oocyst excretion. Parasitol Res 2012; 110(2): 875881. PMid:21808979. http://dx.doi.org/10.1007/s00436-011-2569-z.

Borges FA, Borges DGL, Heckler RP, Neves JPL, Lopes FG, Onizuka MKV. Multispecies resistence of cattle gastrointestinal nematodes to long-acting avermectin formulations in Mato Grosso do Sul. Vet Parasitol 2015; 212(3-4): 299-302. PMid:26129974. http://dx.doi.org/10.1016/j. vetpar.2015.06.015.

Brasil. Ministério da Agricultura Pecuária e Abastecimento. Plano mais pecuária. Brasília: MAPA/ACS; 2014. 32 p.

Bruhn FRP, Lopes MA, Demeu FA, Perazza CA, Pedrosa MF, Guimaraes AM. Frequency of species of Eimeria in females of the holstein-friesian breed at the post-weaning stage during autumn and winter. Rev Bras Parasitol Vet 2011; 20(4): 303-307. PMid:22166384. http://dx.doi. org/10.1590/S1984-29612011000400008.

Bruhn FRP, Lopes MA, Perazza CA, Demeu FA, Santos G, Franco A No, et al. Eficiência técnica e econômica da aplicação de diferentes anti-helmínticos em fêmeas da raça holandesa na fase de recria durante o outono-inverno de 2009. Acta Tecnol 2012a; 7(2): 25-30.

Bruhn FRP, Lopes MA, Santos G, Demeu FA, Perazza CA, Guimaraes AM. Eficácia técnica e econômica de diferentes anti-helmínticos na recria de fêmeas da raça holandesa. Arch Latinoam Prod Anim 2013; 21(3): 173-180.

Bruhn FRP, Silva FA Jr, Carvalho AHO, Orlando DR, Rocha CMBM, Guimaraes AM. Occurrences of Eimeria spp. and gastrointestinal nematodes in dairy calves in southern Minas Gerais, Brazil. Rev Bras Parasitol Vet 2012b; 21(2): 171-175. PMid:22832761. http://dx.doi.org/10.1590/ S1984-29612012000200019.

Cacciò SM, Thompson RCA, McLauchlin J, Smith HV. Unravelling Cryptosporidium and Giardia epidemiology. Trends Parasitol 2005; 21(9): 430-437. PMid:16046184. http://dx.doi.org/10.1016/j.pt.2005.06.013.

Campos OF, Lizieire RS. Criação de bezerras em rebanhos leiteiros. Juiz de Fora: EMBRAPA Gado de leite; 2005. 142 p. 
Carvalho JG, Carvalho AU, Heinemann MB, Coelho SG, Paes PRO, Moreira GHFA, et al. Estudo longitudinal da infecçáo por enteropatógenos em bezerros neonatos, com diarreia, sob diferentes estratégias de aleitamento. Pesq Vet Bras 2014; 34(6): 529-536. http://dx.doi.org/10.1590/S0100736X2014000600006.

Charlier J, Levecke B, Devleesschauwer B, Vercruysse J, Hogeveen $\mathrm{H}$. The economic effects of whole-herd versus selective anthelmintic treatment strategies in dairy cows. J Dairy Sci 2012; 96(6): 2977-2987. PMid:22612935. http://dx.doi.org/10.3168/jds.2011-4719.

Coles GC, Bauer C, Borgsteede FHM, Geerts S, Klei TR, Taylor MA, et al. World Association for the Advancement of Veterinary Parasitology (W.A.A.V.P.) methods for the detection of anthelmintic resistance in nematodes of veterinary importance. Vet Parasitol 1992; 44(1-2): 35-44. PMid:1441190. http://dx.doi.org/10.1016/0304-4017(92)90141-U.

Costa MSVLF, Araújo RN, Costa AJLF, Simões RF, Lima WS. Anthelmintic resistance in a dairy cattle farm in the State of Minas Gerais. Rev Bras Parasitol Vet 2011; 20(2): 115-120. PMid:21722485. http://dx.doi. org/10.1590/S1984-29612011000200005.

Dantas AAA, Carvalho LG, Ferreira E. Classificação e tendência climática em Lavras, MG. Cienc Agrotec 2007; 31(6): 1862-1866. http://dx.doi. org/10.1590/S1413-70542007000600039.

Daugshies A, Najdrowski M. Eimeriosis in Cattle: Current Understanding. $J$ Vet Med B Infect Dis Vet Public Health 2005; 52(10): 417-427. PMid:16364016. http://dx.doi.org/10.1111/j.1439-0450.2005.00894.x.

Dobson RJ, Hosking BC, Jacobson CL, Cotter JL, Besier RB, Stein PA, et al. Preserving new anthelmintics: A simple method for estimating faecal egg count reduction test (FECRT) confidence limits when efficacy and/or nematode aggregation is high. Vet Parasitol 2012; 186(1-2): 7992. PMid:22154971. http://dx.doi.org/10.1016/j.vetpar.2011.11.049.

Ernst JV, Benz GW. Intestinal coccidiosis in cattle. Vet Clin North Am Food Anim Pract 1986; 2(2): 283-291. PMid:3488102. http://dx.doi. org/10.1016/S0749-0720(15)31238-X.

Forslid A, Christensson D, Dahl J, Grandi G, Enemark JMD. Bovine eimeriosis in Swedish calves: Epidemiology and insights into sampling procedures. Vet Parasitol: Reg Stud Rep 2015; 1-2: 16-20.

Geurden T, Vandenhoute E, Pohle H, Casaert S, De Wilde N, Vercruysse $\mathrm{J}$, et al. The effect of a fenbendazole treatment on cyst excretion and weight gain in calves experimentally infected with Giardia duodenalis. Vet Parasitol 2010; 169(1-2): 18-23. PMid:20089358. http://dx.doi. org/10.1016/j.vetpar.2009.12.027.

Geurden T, Vercruysse J, Claerebout E. Field testing of a fenbendazole treatment combined with hygienic and management measures against a natural Giardia infection in calves. Vet Parasitol 2006; 142(3-4): $367-$ 371. PMid:16959430. http://dx.doi.org/10.1016/j.vetpar.2006.07.019.

Gordon H, Whitlock AV. A new technique for counting nematode eggs in sheep feces. J Sci Ind Res 1939; 12(1): 50-52.

Grisi L, Leite RC, Martins JR, Barros AT, Andreotti R, Cançado PH, et al. Reassessment of the potential economic impact of cattle parasites in Brazil. Rev Bras Parasitol Vet 2014; 23(2): 150-156. PMid:25054492. http://dx.doi.org/10.1590/S1984-29612014042.

Guimarães MP, Ribeiro MFB, Facuri-Filho EJ, Lima WS. Strategic control of gastrointestinal nematodes in dairy calves in Florestal, Minas Gerais, Brazil. Vet Res Commun 2000; 24(1): 31-38. PMid:10703752. http://dx.doi.org/10.1023/A:1006373221169.

Hoffmann RP. Diagnóstico de parasitismo veterinário. Porto Alegre: Sulina; $1987.156 \mathrm{p}$.
Huber F, Bomfim TC, Gomes RS. Comparação da eficiencia da técnica de sedimentação pelo formaldeído-éter e da técnica de centrífugoflutuação modificada na detecçáo de cistos de Giardia sp. e oocistos de Cryptosporidium sp. em amostras fecais de bezerros. Rev Bras Parasitol Vet 2003; 12(2): 135-137.

International Business Machines - IBM. Statistical package for the sciences: SPSS statistic 18.0. Armonk: IBM; 2014.

Kenyon F, Jackson F. Targeted flock/herd and individual ruminant treatment approaches. Vet Parasitol 2012; 186(1-2): 10-17. PMid:22188982. http:// dx.doi.org/10.1016/j.vetpar.2011.11.041.

Mundt HC, Bangoura B, Mengel H, Keidel J, Daugschies A. Control of clinical coccidiosis of calves due to Eimeria bovis and Eimeria zuernii with toltrazuril under field conditions. Parasitol Res 2005;97(Suppl 1): 134142. PMid:16228270. http://dx.doi.org/10.1007/s00436-005-1457-9.

O’Handley RM, Ceri H, Anette C, Olson ME. Passive immunity and serological immune response in dairy calves associated with natural Giardia duodenalis infections. Vet Parasitol 2003; 113(2): 89-98. PMid:12695034. http://dx.doi.org/10.1016/S0304-4017(03)00059-1.

O’Handley RM, Cockwill C, Jelinski M, McAllister TA, Olson ME. Effects of repeat fenbendazole treatment in dairy calves with giardiosis on cyst excretion, clinical signs and production. Vet Parasitol 2000; 89(3): 209-218. PMid:10760411. http://dx.doi.org/10.1016/S03044017(00)00200-4.

O'Handley RM, Olson ME. Giardiasis and Cryptosporidiosis in Ruminants. Vet Clin North Am Food Anim Pract 2006; 22(3): 623-643. PMid:17071357. http://dx.doi.org/10.1016/j.cvfa.2006.07.002.

O’Shaughnessy J, Earley B, Mee JF, Doherty ML, Crosson P, Barrett $\mathrm{D}$, et al. Controlling nematodes in dairy calves using targeted selective treatments. Vet Parasitol 2015; 209(3-4): 221-228. PMid:25770853. http://dx.doi.org/10.1016/j.vetpar.2015.02.024.

Philippe P, Alzieu JP, Taylor MA, Dorchies P. Comparative efficacy of diclazuril $\left(\right.$ Vecoxan $\left.^{\circledR}\right)$ and toltrazuril $\left(\right.$ Baycox bovis ${ }^{\circledR}$ ) against natural infections of Eimeria bovis and Eimeria zuernii in French calves. Vet Parasitol 2014; 206(3-4): 129-137. PMid:25458561. http://dx.doi. org/10.1016/j.vetpar.2014.10.003.

Roberts FHS, O'Sullivan PJ. Methods for egg counts and larval cultures for strongyles infesting the gastro-intestinal tract of cattle. Aust J Agric Res 1950; 1(1): 99-102. http://dx.doi.org/10.1071/AR9500099.

Sánchez RO, Romero JR, Founroge RD. Dynamics of Eimeria oocyst excretion in dairy calves in the province of Buenos Aires (Argentina), during their first 2 months of age. Vet Parasitol 2008; 151(2-4): 133 138. PMid:18096320. http://dx.doi.org/10.1016/j.vetpar.2007.11.003.

SAS Institute. Statistical analysis system: SAS user's guide: statistics. Version 9.1.1. Cary: SAS Institute Inc.; 2004.

Silva FA Jr, Carvalho AHO, Rocha CMBM, Guimarães AM. Fatores de risco associados à infecção por Cryptosporidium spp. e Giardia duodenalis em bovinos leiteiros na fase de cria e recria na mesorregião do Campo das Vertentes de Minas Gerais. Pesqui Vet Bras 2011; 31(8): 690-696. http://dx.doi.org/10.1590/S0100-736X2011000800010.

Souza AP, Ramos CI, Bellato V, Sartor AA, Schelbauer CA. Resistência de helmintos gastrintestinais de bovinos a anti-helmínticos no Planalto Catarinense. Cienc Rural 2008; 38(5): 1363-1367. http://dx.doi. org/10.1590/S0103-84782008000500026.

Ueno H, Gonçalves PC. Manual para diagnósticos das helmintoses de ruminantes. 4nd ed. Tokyo: JICA; 1998. 